\title{
Cooperative Indexing: a Postwar Program Today
}

The culmination of a bibliographical project of the A.L.A. Junior Members Round Table is here described.

$\mathrm{W}$

ITH THE PUBLICATION of "Local Indexes in American Libraries"1 scheduled for the near future, a new avenue will be open to libraries for cooperative indexing. A five-year project of the Junior Members Round Table of the American Library Association, the completed work is a union list of unpublished indexes in libraries of the United States, Canada; the Hawaiian Islands, and Puerto Rico.

Cooperative indexing is not a new idea in library circles, but unfortunately only a few libraries have been able to enjoy its benefits. Inadequate knowledge of existing indexes is the main reason for this condition, which now is to be partially remedied. Joseph L. Wheeler, librarian of the Enoch Pratt Free Library of Baltimore, has long advocated cooperative indexing and has already used the unpublished "Local Indexes" to make a study of certain needs in this̀ field. With the appearance of this work in print, approximately 950 libraries will reveal their special card files to librarians and scholars.

Material for the list has been secured by means of questionnaires sent to libraries and by extensive publicity in library publications. The survey was conducted by state and national committees of the round table

1 The author reports that "Local Indexes" is planned for publication by the F. W. Faxon Company in late 1944 or early 1945. working in the various types of librariespublic, college and university, school, and special. Information on each index received includes subject, form, arrangement, scope, size, and frequency of additions.

Over 2500 subjects are represented in the bibliography, which includes almost eight thousand indexes. The topics vary widely, from the most popular ones of the day to some of the most highly specialized, scholarly, and technical subjects possible. It is for these latter indexes that the list is most valuable to college and research librarians, both for informative purposes and for aid in special reference work.

\section{General Subjects}

Robert Alvarez, in his article "Needed! A Union List of Card Files," 2 outlines five types of files found in libraries. The first type is the file useful in any library and, in our opinion, the file most suitable for cooperative indexing. This type includes general subjects such as plays, short stories, poetry, etc. Supplements to published indexes are issued too few and far between to help the average library keep up with current requests. Cooperative indexing would not, however, take the place of published indexes. Such indexing would undoubtedly be done on lightweight, inexpensive cards, and files would be weeded out on publication of the various indexes. Since most libraries are already cramped for space, it stands to reason that additional

${ }^{2}$ Library Journal 64: 395-96, May 15, 1939. 
card files would in no sense be permanent.

It is interesting to note the subjects which have been indexed the most frequently - topics for which, therefore, cooperative indexing is most needed. A check of "Local Indexes" reveals the following subjects to be the most popular, according to the number of libraries which have supplemental indexes: plays, I76; short stories, I25; pictures, 107; biography, I06; vocations, 84; reference aids, 77 ; debates, 68 ; poetry, 67 ; songs, 66 ; music, 62 ; fiction, 60 ; genealogy, 55 ; holidays, 42 ; maps, 34 .

These figures do not include indexes for related subjects or for subdivisions of the main subject. Neither do they include small indexes or those limited to material in one library, such as picture files; such indexes have been omitted from the list. The majority of files are author, title, and subject indexes to book and periodical material, that is, material unindexed and supplemental to published indexes.

Several hundred individual magazines and newspapers have also provided a fertile field for indexing. State and local periodicals, especially valuable for material not found elsewhere, have in many instances been indexed in duplicate by several libraries. For example, in California we have a little magazine called $W$ estways, which is filled with excellent state and local information about places and events. Seven different California libraries have indexed this magazine, in most cases even the same volumes and years. If one is at all familiar with indexing procedure, it is easy to calculate the many hours of professional or other time needlessly spent on this work. Cooperative indexing would have saved a great deal of money and released staff members for more important effort.

All state and local subjects have been minutely cross-referred in "Local Indexes," making such material quickly available for future cooperation.

\section{Music and Art}

Music librarians have long deplored the lack of adequate indexing services in their field and are constantly striving for better tools in their profession. In our union list, in addition to the general indexes on music and songs already mentioned, there are well over one hundred specialized indexes listed ; including, for example, indexes to program notes of all the major symphony orchestras. Reproduction of the best of existent files and plans for future cooperation in this one topic alone would be of invaluable aid to music patrons and librarians.

Art and related subjects are likewise represented by innumerable indexes and include a great deal of information not found elsewhere. Portraits, illustrators of children's books, sculpture, and painting are only a few of the subjects available.

\section{Future Publications}

Another very important use of "Local Indexes" will be its use as a basis for future published compilations. In most cases libraries are glad to open their files to librarians who are working in the fields they have indexed, because they themselves have neither time nor desire for publishing. Of course it is understood that the indexes are not for wholesale copying but are only to be used to supplement work already started and to help solve problems. Then, too, such indexes often supplement each other. A library may have only an author index to a certain topic, while the person who expects to publish plans a title and subject index as well. Obviously the library will be more than repaid for any assistance it may render.

There are some libraries, of course, which guard their indexes with their very lives, with a "no touch" sign for the patron, be he librarian or other. Fortunately these libraries are few, because certainly they defeat their own purpose. 


\section{A Practical Plan}

After publication of "Local Indexes in American Libraries," it seems expedient that a practical plan for cooperative indexing be devised. While individual libraries will, of course, seek out nearby indexes of local or special significance, there should be, nevertheless, some central control for future work on a national scale. What would be the best system? There are several possibilities for such direction that present themselves:

I. By state library associations: To plan for cooperative indexing of state and local periodicals, documents, and books of historical value; to combine and reproduce these files for the use of all libraries in the several states.

2. By divisions of the American Library Association: To designate the indexes of special interest to various fields, i.e., college and research libraries, work with children, etc; each division to work out its own plan of cooperation.

3. By the Reference Librarians Section of the Association of College and Reference $\mathrm{Li}$ - braries: Since the projects are of chief value in reference work, this section could well direct plans, subdividing responsibility according to type of index (e.g., technical) or type of library (e.g., special).

4. By the Junior Members Round Table: To carry on work of "Local Indexes" by means of a cooperative indexing committee, in collaboration with the various national and state library associations.

There are advantages to each form of control, and it is difficult at this time to decide that any one is best. In fact, it is possible that a combination of all four might well be employed. Certainly there will be a sharp division of interest in the indexes, and this fact must be taken into consideration before any plan is adopted.

Cooperative indexing is certainly one postwar program which can be started today and one which should mean a great deal in the future of our profession. In these days of limited staff and budget, it seems advisable to consider carefully any such program because of the time and money it may save for libraries.

\section{Postwar Information Bulletin}

THE Postwar Information Exchange, representing forty-odd research and educational bodies concerned with national and international postwar matters, is planning issue of a four-page monthly entitled Postwar Information Bulletin. This is designed to carry the pooled information from the agencies in the exchange and to aid discussion leaders, program chairmen, teachers, librarians, and others in guiding the consideration of postwar problems. Subscriptions are announced as at the rate of one dollar per year and may be sent to the Postwar Information Exchange, 8 W. 40th St., New York City 18. 